\title{
Revamping the Popular in Snow White and Pubis angelical: The Residual Fictions of Donald Barthelme and Manuel Puig
}

\author{
Alejandro Herrero-Olaizola
}

Donald Barthelme (1931-1989) and Manuel Puig (1932-1990) are exemplary of how U.S. and Latin American writers have revamped popular discursive forms by presenting in their fictions both parodies and stylizations of such forms. Barthelme's better-known works-Snow White (1967), The Dead Father (1976) and The King (1990)-rewrite folktales and legends from a twentieth-century perspective, critiquing consumerism, politics, sexual freedom and family relations in U.S. society. For his part, Manuel Puig's use of serial literature in Boquitas pintadas [Heartbreak Tango] (1969), detective fiction in The Buenos Aires Affair (1973), or the cinematic melodrama in El beso de la mujer araña [Kiss of the Spider Woman] (1976) overlaps with political, psychoanalytical or historical interpretations of twentieth-century Argentina. The pervasiveness of parodic popular narratives such as these is indicative of a change of dominant discursive forms in contemporary U.S. and Latin American writers. Novels like Puig's and Barthelme's reject the literary canon's division between high and low cultural manifestations. Rather, they blur the differences between low and high types of discourses.

Traditionally, the study of popular literature is based on a distinction between serious literature (erudite, canonical, elitist) and trivial literature (second-rate, entertaining, of the masses or popular), the latter being derived from the former. Popular fiction is understood as a re-collection of the remains and scraps of the permanent values exposed in serious literature, and it often presents a literary model commonly considered "cultural detritus" (Ashley 1-3). Thus, popular literature is seen as a residual part-and, as such, as inferior and subverted — within a hegemonic literary system.

In the case of contemporary U.S. and Latin American fiction, this distinction becomes problematic. Popular literature's apparently limited importance gets to be questioned, since its residual nature becomes nec- 
essary for the validation of serious (and dominant) literature. While some critics might characterize Manuel Puig's and Donald Barthelme's fiction as "rubbish," "junk" or "residue" (Radford 6-7), others would argue that these authors-far from writing trash-use popular forms in order to revamp them, to rid them of their residual nature, and to incorporate them as serious modes of artistic expression.

The conflation of distinct modes of literary discourse in many contemporary U.S. and Latin American texts of fiction tends to blur the differences between serious and other non-serious narratives. ${ }^{1}$ The fragmentation of elitist fiction and its incorporation of popular forms creates a fiction that is at once academic-elitist and also accessible-popular (Hutcheon, Poetics 20). However, texts such as Puig's and Barthelme's problematize this incorporation of the popular by embedding it in a formal narrative complexity. In fiction by Puig, Barthelme and others, one could argue that Hutcheon's bimodal model has been rewritten as "academic-popular" and "elitist-accessible." Parody-as "a perfect postmodern form" (Hutcheon, Poetics 11) - may be seen as an essential parameter in such textual transformation. This transtextual operation is based on the relation between a present text that attempts to transform and/or incorporate a previous text which becomes the object of parodic exposition. However, this operation is profoundly ambivalent in the case of popular formulae: it is produced by incorporating the original text that it subverts and parodies, while simultaneously privileging and stylizing these popular narratives in the present text. Since a privileged position between the original text and the present text does not exist, parody becomes the decentering agent of an original and monolithic meaning as it privileges and/or subverts the alternation between "Culture" (high, elitist) and "culture" (popular, mass).

The works of Barthelme and Puig are exemplary of how U.S. and Latin American contemporary fiction have insisted that there is no one single popular discursivity, that the popular per se does not exist. Pubis angelical (1979) and Snow White (1967)-the examples from Puig's and Barthelme's fictions chosen for discussion here-cannot be labeled exclusively as popular literature nor read exclusively as canonical or elitist texts. In each, the idea that a monolithic center representing a "new center," or new canon, according to which the popular would draw nearer to the elitist and vice versa, does not exist. In a sense, these texts point out that the revamping of popular formulae establishes a new literary canon-due to its high frequency in the production of the Spanish American novel (Sklodowska) as well as in U.S. fiction (McCaffery).

As suggested by my reading of Barthelme's and Puig's texts, Pubis angelical and Snow White do not eschew their popular labeling, but 
rather, they transform their popular nature. They call into question a "popular versus serious" differentiation, as they emphasize the intermingling and blurring of both. The fiction of Barthelme and Puig tends to present science fiction, Hollywood melodramas, folktales, and "pop" culture of the 1960 s as alternatives to the traditional uses of popular materials. Their texts are residual narratives which aim at eliminating the negative connotations of the term by going beyond the realm of the residual. Puig's and Barthelme's texts include formulaic narratives while pointing to a high culture zone. Reading such narratives might be dismissed as trivial or lacking in high cultural values but their popular nature is only apparent, given their discursive richness. Barthelme's and Puig's texts broaden the critical field through their manifest interdiscursivity, resisting to generic delimitations. Such hybridization of the folktale, television melodrama, science fiction in Snow White and Pubis angelical (de)form and revamp the popular formulae from which their narratives are fed, at the same time that they transform the notion of popular literature and widen-through parody - the discursive spectrum.

$$
\text { *** }
$$

Barthelme's Snow White recuperates a series of literary remains or left-overs extracted from popular knowledge of the story of Snow White. This residual character defines the poetics of the text that combines the popular collective familiarity with Snow White's story and a selective narration by Barthelme based upon it. ${ }^{2}$ Although it is difficult to establish a linear narrative in the text, in broad terms, Snow White tells the story of a young woman with literary aspirations who lives with seven dwarves (Bill, Dan, Kevin, Edward, Hubert, Henry, and Clemen). She shares with them her long and erotic showers in an apartment in Lower Manhattan, reproducing a communal system typical of the 1960s. The dwarves work as janitors, and make Chinese food for children, as well as plastic humps. The protagonist, in spite of being spied upon by the quasi-aristocratic Hogo de Bergerac, waits for the arrival of the rescuing Prince Paul, a man completely lacking in initiative. Jane (the equivalent to the stepmother in the Grimm's version) desires the "vile" Hogo andafter feeling rejected by him-tries to poison Snow White with a glass of vodka. The denouement of Barthelme's text varies from the traditional version: the protagonist, spurred on by her intellectual misgivings, rejects her role as a passive, waiting woman and leaves the field open for Prince Paul to drink the poison prepared by Jane. This ending seems happy for the protagonist, an ending which one might suppose to be her liberation, that is, her rejection of a passive role.

At first glance, Barthelme's version seems to originate in the Disney version, but it includes elements of the Grimm version as well as others 


\section{Journal of Popular Culture}

derived from oral tradition. The difficulty of establishing an original text undercuts the idea of any central or monolithic authority, and critics have pointed out that, if indeed the original story by the Brothers Grimm comes to mind before beginning to read the novel (Horn 272), we ought not forget that multiple versions of the story-including Walt Disney's (Morace 2)-must be taken into account at the moment of considering the amalgam of texts and versions of Snow White's story used by Barthelme.

If we were to read Snow White without any consideration of previous versions, we would confront, at the very least, an incomplete reading. Snow White self-consciously promotes a critical and evaluative operation which is realized by the contrastive nature of the narration, the questionnaire, and the headings that evaluate the text's relation to previous texts. Such texts recycle previously used literary formulae to both question and surpass them. Snow White defamiliarizes a series of exhausted folktale models and this defamiliarization operates on the base of a parodic exposition: Barthelme's text alters the popular narration of Snow White's story and, simultaneously, revises interpretations of this narrative by including a wider reflection on literature, language, psychology, history, and feminism.

The fragmentary nature of Barthelme's story is highlighted by typographical alterations in the text, specifically a series of headings in boldface that occupy entire pages. These alternate with the story's narration to enunciate its thesis about the protagonist's psychological condition (16), or to comment on themes apparently unrelated to the story being told. The narrative likewise fragments the folktale and initiates a reflexive discourse regarding literature and language according to a parodic revision of what is narrated in other previous versions. This discourse emphasizes the residual character of Barthelme's fiction, which-in a sense-plays with the idea of being "junk literature" since it claims that popular literature's residual character is an essential resource of modern art.

This "junk poetics" is obvious in Barthelme's novel: the seven dwarves do not work happily in the forest, but rather, make "Chinese baby food: BABY BOW YEE (chopped pork and Chinese vegetables), BABY DOW SHEW (bean curd stuffed with ground pike)" (18). The dwarves' work is supplemented with other activities that point to their function as producers of trash, as agents who manage the garbage (janitors), or as promoters of useless objects like plastic humps or junk food. Snow White's poetics of junk reflexively focuses attention on the implications of junk production in twentieth-century American society. Dan, one of the most outspoken characters, openly reflects on this issue: 
[Y]ou will agree, the question turns from a question of disposing of this "trash" to a question of appreciating its qualities, because, after all, it's 100 percent, right? And there can no longer be any question of "disposing" of it, because it's all there is...that's why we're in humps...more really from a philosophical point of view than because we find them a great moneymaker. (97)

The dwarves' occupation clearly contrasts with their work in previous versions: here the dwarves are not industrious, productive individuals mining jewels in the forest but individuals who immerse themselves in the industry of promoting junk. Whereas the folktale suggests that the dwarves contribute positively to society by their labor, Snow White parodies this activity, suggesting that the only thing produced is trash. In Barthelme's text, the dwarves do not perform a positive function in society, lack definitive personalities, and are presented without any detailed description. It is almost impossible to differentiate among Bill, Dan, Kevin, Edward, Hubert, Henry, and Clemen, in contrast to the highly recognizable differences in the Disney dwarves ("Dopey," "Grumpy," etc.). The dwarves' attitude is geared toward a poetics that expands residues of other narratives, and ultimately defends the artistic values of trash. One might conclude that Barthelme's Snow White not only parodies the folktale but converts it into garbage, destroying the popularity of Snow White by trashing Snow White. Barthelme's text consciously reflects on this trashing exercise and fosters an appreciation of the qualities associated with residual fiction. When the dwarves declare "we like books that have a lot of dreck in them...which can supply a kind of 'sense' of what's going on" (106), they advocate a literature that integrates popular fiction while degrading it (i.e., presenting it as something residual), and yet they claim artistic value for it. Their reaction to Snow White's literary intentions, specifically her writing of "a dirty great poem four pages long" (10), is not surprising. Although the entire poem is never reproduced in the novel, some excerpts are included in the text $(12,31,43,59-60,72)$, and, through these, one deduces that it is a love poem intended to be serious literature. Snow White's interest in writing and abandoning the role of submissive woman, however, appears to disgust the dwarves because of its non-popular literary qualities. The initial lines of the poem contain the phrase "bandaged and wounded." The dwarf Dan critiques the line as "a metaphor of the self armoring itself against the gaze of the Other" (59-60) expressed through language that only has a "filler" effect. According to Dan, language serves to embroider discourse, to round it out, and, finally, to convey in itself absolutely no meaning: "the 'filling' you might say, of which the expression 'you might say' is a good example, is to me the most interesting part [of lan- 
guage]" (96). This conception of language fits clearly within the residual and vacuous nature that the dwarves confer on literature as well as literary discourse, and suggests that language changes according to cultural codes or norms, functioning as a tool for displacement (Courtier and Durand 19).

Snow White takes up this idea of language's filler effect to expand its discursive dissemination in accord with its poetics of trash. The text widens the discursive spectrum by revising of the folktale's traditional relationship between the prince and the female captive. Here Prince Paul is a hen-pecked man while Snow White is a "liberated" woman, and we find an implicit reflection on feminism articulated by this role reversal between Snow White and Prince Paul. Barthelme's Snow White is open to the tenets of the women's liberation movement of the 1960s and 1970 s as shown by her literary aspirations and her constant erotic showers with the dwarves-who, given their physical handicap, must take turns and work together to satisfy her. The rescuing prince in this text more closely resembles the traditional Snow White. Prince Paul is passive, and possesses neither a kingdom nor a any compulsion to power (27-28). Paul's passivity originates in his lineage. His father is characterized as a mature man of lesser intelligence from whom he inherits his role as a doubtful rescuer. The victim of his own passivity, the prince dies after drinking a "vodka Gibson on the rocks" specially prepared (and poisoned) for Snow White (174). With the reversal of the Grimm and Disney ending, we note that Snow White's passivity in the popular version leads to a similar fate when it is taken on by the prince in Barthelme's version.

Snow White emphasizes this inverted relationship between the captive princess and the prince in the protagonist's consciousness-raising which changes her status as a "lady in waiting." This required wait is parodied in one of Snow White's monologues. A half-page listing of the names of her possible rescuers-"Which prince? Will it be Prince Andrey? Prince Igor? Prince Alf? Prince Alfonso? Prince Malcolm? Prince Paul?..." (77) - is interrupted by the protagonist's recognition of her role as "lady in waiting" and of her expression of dissatisfaction with that role. She declares: "I would rather be doing a hundred other things" (77). Barthelme's alteration of the traditional model is thematized in the headings which parody the protagonist's submissive role- "THE HORSEWIFE IN HISTORY" (61)—as well as her more intellectual active role: "SNOW WHITE THINKS: WHY AM I... GLASS...HUNCHED AGAINST THE WALL" (166). The graphic distribution of the headings stresses the text's discursive fragmentation and emphasizes its solipsistic nature by not leaving any residual material, by 
not making obvious the different pieces of the discursive amalgam that constitute its poetics (Courtier and Durand 69).

To complete the disseminating effect of these headings, Barthelme incorporates a questionnaire which divides the first two parts of Snow White. A first set of questions relate the novel's characters to their possible identification with previous models (questions 1-4, 11)-for example, "Does Snow White resemble the Snow White you remember? Yes ( ) No ( )" (82). Other questions encourage the reader to compare the novel to previous models, and explicitly suggest a sporting or playful effect: filling in the blanks to signal our choice is a game didactic in nature. As Hutcheon points out, parody teaches us how the text we are reading is constructed $(1985,15)$. As readers, we reexamine our familiarity with the story, and in so doing we become critics, ultimately transforming our own familiarity with the folktale. Barthelme's text invites a wider reading of Snow White's story: we are explicitly encouraged to question the popular genre and this opens the possibility of a wider discursive spectrum.

A second set of questions proposes an evaluation of certain narrative techniques used in the text (questions 5-7, 9, 13): "In the further development of the story, would you like more emotion ( ) or less emotion ( )?" (82). By incorporating these questions, the text refers back to its condition as a folktale and produces a "reversal of the fairytale" effect (Horn 272-73). This textual strategy of "inversion" is made explicit following a third set of questions $(8,10,12,14,15)$ which-although indeed some are related to writing - are distant from Snow White's story and the process of its writing. They show the need to step out of the literary model that the text expounds. This last group of questions calls the two previous groups into question, thus parodying its own status as an evaluative text: "In your opinion, should human beings have more shoulders? ( ) Two sets of shoulders? ( ) Three? ( )" (83). Questions such as this one do not refer to the text, but rather to the simple condition of being a question, similar to the "filler" effect as laid out by Dan in the narrative. ${ }^{3}$

The questionnaire and headings foreground Snow White's residual nature by its use of familiar characters and motifs in unfamiliar ways. Snow White self-consciously incorporates these motifs and characters, to achieve a parodic effect and to reify an interest in parodying/stylizing the genre through which it expresses itself: "The story is not just a modernized...reversal of the original fairy-tale. Thus, the original text appears in Barthelme's book in two layers: as its absolutely modified story and as shreds torn out of the original text" (Horn 272-73; my italics). The parodic version offered by Barthelme's novel is, to a certain 
degree, a revision of the folktale genre, but it maintains a folktale's structure. It begins with the description of the protagonist, her flight and hiding-out, her waiting, and then, the denouement. Whereas the folktale's happy ending provides a sense of closure or completion, Barthelme does not focus on the structural elements of the story but on the residue of the story, using fragments that expose a variety of discourses. Barthelme's Snow White ends inconclusively, offering various possibilities for completing the story, in accord with a list of options in the last page of the novel: "THE FAILURE OF SNOW WHITE'S ARSE, REVIRGINIZATION OF SNOW WHITE, APOTHEOSIS OF SNOW WHITE, SNOW WHITE RISES INTO THE SKY, THE HEROES DEPART IN SEARCH OF A NEW PRINCIPLE HEIGH-HO" (181). This list does not offer endings but rather beginnings, points from which the story can be re-told once again, as yet another critical exercise about itself. These reexamine the folktale's history and recuperate a popular genre but blur the traditional distinctions between it and serious literature. Barthelme advocates incorporating these residual elements of "culture," which are recycled as part of a discursivity proper to "Culture."

Barthelme's folktale is not simply a popular fiction, or simply a critical, feminist, or historical reading constructed upon the foundation of that fiction. Parody makes possible a discursive dissemination that calls for a re-consideration of the fictional nature of the text. Snow White does not correspond exclusively to popular fiction, in which the events of the story (what happens to Snow White and the seven dwarves) are the most important elements. Rather, to read Barthelme's novel is, simultaneously, to read a hybrid text that includes critical interpretations of that fiction, and offers a amalgam of previous versions within the historical context of U.S. society in the 1960 s.

$$
* * *
$$

Manuel Puig's Pubis angelical (1979) uses the cinematic melodrama, the woman's diary, and science-fiction to tell the stories of three women-"la bella," Ana, and W218-whose lives span from the early 1930 s through the twenty-first century. One narrative line is situated in Mexico in 1975 and tells - in the guise of a television melodrama or soap opera - how Ana convalesces in a hospital after having a cancerous tumor removed. Her story comes to us through dialogues with her visitors Beatriz-her confidante with whom she converses about men and feminism-and Pozzi-a political activist who wants to set a trap for her ex-lover Alejandro-, as well as from extracts from her personal diary (Part One: chapters 1-6, 8; Part Two: chapters 9, 10, 12, 13, 14, 16). 
Another narrative line takes up the cinematic melodrama: set in Vienna and Hollywood in the 1930s and 40s, it tells the tragic life of "the world's most beautiful actress" and her supernatural powers to read minds. "La bella"- - who is also called "el Ama"-is the victim of multiple vexations on the part of men: her husband-a Viennese munitions maker-keeps her trapped in his mansion; the servant Theo with whom she escapes tries to murder her; and the Hollywood leading man with whom she works disdains her, ultimately causing her accidental and tragic death (Part One: chapters 1, 3, 4, 6, 7). The science fiction line takes the story of the 1930 s into the twenty-first century, a new "Ice Age." A female descendant of "la bella"- the conscript W218-will also be betrayed by a man. Through the Supreme Government's Sex Therapy Program, W218 finds herself involved in espionage with a governmental agent LKJS which ends with her exile to a colony for the terminally ill in the Eternal Ice regions (Part One: chapter 8; Part Two: chapters 10, 11, $13,15,16)$.

Given the variety of popular literary formulae in this novel, Puig, undoubtedly, excels in being a popular author in Pubis angelical. His narrative is fed by these formulae in a playful manner: there is a tendency to parody and to stylize the literary models that these formulae have traditionally expressed. A clear example of this are the multiple and interminable betrayals of the three protagonists. "La bella" is systematically betrayed by the men who pass through her life: first, by her husband who keeps her as a prisoner in his mansion and often drugs her (11); secondly, by the servant Theo, a Soviet agent who helps her escape only to rape her (81); and finally, by the Hollywood directors, leading men, and the press (110-12). The other two protagonists find themselves betrayed as well: W218 in her relationship with Agent LKJS (236) and Ana by her ex-lover and by Pozzi (35-40).

Pubis angelical stylizes these popular narratives-film and television melodrama, science fiction-and also presents an analysis of how they can be revised vis à vis a series of stereotypes in the text. Reading Pubis angelical suggests that we consider these two possibilities in an intricate manner: one might speak of the dual movement of parody/stylization in terms of a "double voiced discourse" in which the author's intention does not spring from the direct discourse, but rather from the discourse of the other (Bakhtin 179). In Puig's novels we usually find an ambivalent narrator who manipulates someone else's discourse and whose presence is effaced. Yet this narrator remains present behind the scenes as someone who appears and disappears (Kerr 105). Puig's "disappearance" as a controlling central presence corresponds to the location of an individual, original author in popular literature. As a writer in a 
popular manner, Puig in effect co-authors the text; that is, he writes a text that, to a certain degree, has already been written by others, a text made of residues of various discourses. This ambivalent role of the author favors the manipulation of popular discourses such as Ana's almost soap opera-like melodrama or W218's science fiction, and nonpopular discourses such the discussions on Lacanian psychoanalysis and Peronism between Ana and Pozzi (169-72) or the comments on feminism between Ana and Beatriz.

Due to its fragmented and residual nature Pubis angelical eschews any notion of a central organizing discourse. Rather, it operates on the same popular level as the narrative lines. For example, Ana's narrative line parodies the TV-style dialogues as well as the women's diary format and yet coexists with her musings on feminism:

But let's go back to the reasons for this diary.... According to her [Beatriz] a woman has problems because she wants, she pretends to be a man and not a woman.... And how right she is, that's the mistake, not accepting our position as women, as sentimental dolls, what can we do?... But it has to be acknowledged that it's fine to be always taking care of ourselves, and making ourselves pretty, because it's so much fun to see someone get worked up over you. Of course, that rules out the ugly ones, that's why they bother with feminism (16-18; translation by Elena Brunet)

Clearly, Ana's diary contains a discourse that does not belong to her. Reading Ana's discourse, we also read Beatriz's and simultaneously read the parodic manipulation of both by an authorial figure that "disappears." In Baktinian terms, the author here "manipulates another speech act in the direction of his own intentions," such that discourse becomes a battlefield of opposing intentions (185). Whatever is exposed in the discourse of the other is critically evaluated, as Ana evaluates Beatriz's views on feminism and reclaims a series of women's rights. However, Ana misinterprets Beatriz's feminist beliefs, manipulating her friend's discourse to produce a perspective which assumes that a woman's condition implies being flirtatious and feminine. Ana's diary reflects a popularization of feminist discourse, which operates in accordance with a popular formula (the melodramatically toned diary) in order to express a "serious" discourse. ${ }^{4}$

Pubis angelical does not establish a feminist discourse based on Ana's story; rather it reflects on her life and popularizes it through the exaggerated views of the protagonists as if it were a combined view. Ana's views on feminism are also expressed through other popular narratives in the text. Critics have proposed that Ana, "la bella" and W218 
respond to the same motif of "woman dominated" by their husbands/lovers and by a society that promotes masculine domination in the past, present, and future (Bernal 996-97, Jessen 481, Lewis 531). If we accept a familial relationship between the three women, then Ana may be considered the discursive representative speaker for "la bella," W218, and for herself: Ana elaborates her views on feminism based on her experience and on that of her past and future family. ${ }^{5}$

The idea of the submissive or oppressed woman is reinforced by the presentation of the macho dominador ("the dominating super-male") in the novel. This parodic presentation of an initiation ritual for male empowerment in the twenty-first century include all male protagonists of novel, the munitions tycoon, Alejandro and LKJS. In this ritual, the macho dominador becomes an institution in the Ice Age as a part of government programs to initiate little boys in "exercises of power" undertaken to make the most of their machismo:

Boys of today, men of tomorrow, males of the world, be united. You have been selected...because you are the pride of the nation...the attacking and triumphant penises of tomorrow...you shall crush with contempt the natural enemy, the female.... Boy of today, male of tomorrow: humiliate the female, be convinced within yourself that she is inferior to you.... She is not stupid, damned creature, but make her believe that she is, because if not, the kingdom of this planet shall be hers. (206-07; translation by Elena Brunet)

This parodic exposition via science fiction accentuates an opposition already made explicit by the text between the normal world of Ana and "la bella" and the paranormal world of W218. Science fiction reproduces and reaffirms a series of stereotypes accepted in "real" society in conjunction with a spatial and temporal distancing. By parodying these stereotypes, Pubis angelical superimposes an evaluative character on them, so that the use of science fiction to establish the feminist discourse, on one hand, affirms this discourse, and on the other, confounds it. For McHale, the use of science fiction motifs such as a "new order" that arises from a holocaust and/or apocalypse is not uncommon in postmodern fiction since fantastic and science fiction narratives are "governed by an ontologic dominant" (56-68): "Indeed, it [science fiction] is the ontological genre par excellence" (59).

Likewise, the use of science fiction in the text widens the novel's historical context. Through the Supreme Government's institutional prostitution program which designates W218 as a "sexual therapist," the totalitarian and repressive system of Argentine dictatorship in the 1970s is parodied. This historical context is also the subject of a dialogue 
between Ana and Pozzi in the hospital (see primarily 21, 51, 58, 98-100, 114-25, 143). The popular narrative coincides with an historical-political discourse: the text echoes the role of the montoneros during the 1970s and their interest in restoring Peronism in Argentina. This historical situation, however, is situated in the future, in an "ice age after the atomic age." Just as Pozzi fails in his attempt to kidnap Alejandro, Ana's exlover, in order to exchange him for two political prisoners, W218 fails in her attempt to undermine the Supreme Government's totalitarian political system and falls into the hands of LKJS. Both female protagonists confront this discourse of repression with ignorance. Ana declares to Pozzi that "all those things about Argentine politics you're going to have to explain to me, because I never could understand about Peronism" (40), and W218 does not question the government electronic assistance system that requires her at all times to input her thoughts into a microcomputer (182-83).

If indeed science fiction follows a movement that overturns a previous model through parody, it also offers the affirmation of that model, so that the futuristic presentation may have a model of the world about which it (science) fictionalizes. Thus the political dialogues between Ana and Pozzi appear transformed in LKJS and W218: in each case the male maintains a didactic relationship with the female. The construction of such an historical-political discourse is presented in a refracted, fragmented fashion: Pozzi is not a montonero-a resistance fighter against the dictatorial regime-but a sympathizer, who finds himself involved in the kidnapping of Ana's husband, "a right-wing extremist" (103). The plot reconstruction of the events leading up to the kidnapping attempt of Ana's ex-lover is fragmentary. Jessen concentrates on the historical events during the years 1955-1969, from the Illia administration to the Onganía administration, and considers Pozzi a representative of the "left-wing Peronist" who campaigns for Peronism as a means to end the dictatorial regime of 1976 (483-84). Pozzi might also be read as having an emotional as well as a patriotic interest in kidnapping Alejandro, since he is Ana's ex-lover.

We can see how the historical discourse can be reproduced in what is narrated in the popular style: Ana, sick and decrepit, represents a cancerous Argentina and its political instability; Pozzi represents the intellectual who wants to rescue her on her deathbed, reasoning with her and calling upon her sensibility. Cheever's analysis allows the Ana-Pozzi relationship to be extended to the various popular narrative lines that fragment the novel: "the bizarre stories ["la bella's" and "W218's"] emphasize not only the surrealistic nature of Argentine politics, but also...the lunatic world that might be produced if 'leftists,' 'Peronists,' or 
'leftist Peronists' manage to have their way" (68-69). Such a possibility points to the construction of an historical-political discourse based on the popular. The story of W218 also parodies the authoritarian regime that Ana and Pozzi discuss in the hospital.

Ultimately, no single discourse prevails or constitutes-in Cheever's words - "a unifying factor," since Puig's text is made of residues. A reading of Puig's text based exclusively in its psychoanalytical or its historical discursivity would not explain the (de)formative character of the popular narrative in which such a discursivity is conveyed. There is a tendency to posit one discursivity as dominant or as an interpretative key to the text: whether this be historical-social, popular, or psychoanalytical. Whatever the potential validity of such readings may be, Pubis angelical's combination of disparate discourses renders it a residual and hybrid fiction based on the transformation of popular narrative forms.

\section{Notes}

'Interestingly, many contemporary U.S. and Latin American writersdespite the diverse social or economic conditions in which their fictions are produced-appear to engage in similar complex narratives that combine both popular and decidedly non-popular discursive forms. For instance, detective fictions like Manuel Puig's The Buenos Aires Affair (1973) or Mario Vargas Llosa's ¿Quién mató a Palomino Molero? (1986) include sociological commentaries on political and sexual repression in Argentina and Peru. Ishmael Reed's Yellow Black Radio Broke Down (1967) or E.L Doctorow's Welcome to Hard Times (1960) use the western novel (or western films) to reexamine the American Dream today by looking at the nineteenth-century idealization of the Old West. Likewise, social conditions of twentieth-century life have been examined in science fiction works like Manuel Puig's Pubis angelical (1979) or William Burroughs's The Soft Machine (1961), in folktales like Donald Barthelme's Snow White (1967) or The Dead Father (1976), and Gabriel García Márquez's La increíble y triste historia de la cándida Eréndira y de su abuela desalmada [Innocent Erendira] (1972), as well as serialized novels such as Mario Vargas Llosa's La tía Julia y el escribidor [Aunt Julia and the Scriptwriter] (1977).

${ }^{2}$ Barthelme's Snow White offers a selective narration based upon the Brothers Grimm version and divided into three differentiated parts: Part I (2-83) contains forty-six sections, Part II (87-132) twenty-six sections, and Part III (135-81) twenty-five sections all written in a collage mode. Each section contains narrative elements atypical of the folktale such as a fifteen item questionnaire at the end of Part I (82-83) and a series of pages with headings-in boldface and capital letters-which announce historical, literary, and philosophical 


\section{Journal of Popular Culture}

themes $(17,24,39,47,54,61,76,96,115,143,150,165,166,178,181)$. The questionnaire and the headings are intercalated with the story.

${ }^{3}$ Following this idea of displacement, the decline of language in literary discourse is exposed. Maltby sees this decline as reflecting the current state of language, and as explaining how the possibilities for communication between contemporary authors and readers are based on a diminished value in language that presupposes "the proliferation of dreck" (56) [see also Stott 381, Bruss 130].

${ }^{4}$ Ana's views on feminism have been analyzed by critics in distinctly different ways: for Yúdice it represents "un discurso de 'loca' y no de mujer" ("not a woman's discourse, but the discourse of a "flaming queen" "[my translation]) similar to Molina's in El beso de la mujer araña (43); for Bacarisse, it is Ana's initiation as a feminist (365) and for Slotorevsky it is a "female triumph of the acquisition of knowledge"; [my translation] (10). These analyses question how we are to interpret what Ana divulges in her diary and in her dialogues, and to what point it ought to be taken seriously (Kerr 197).

sAmong these familial experiences, note how "la bella" is harassed by a leading man- "Puta inmunda, yo no soy como tú, un mero objeto sexual, yo quiero atraer por mi intelecto" (110) ["Filthy whore, I am not like you, a mere sexual object, I want to captivate with my intellect" (91)]-, or how W218 is degraded by LKJS: "Yo hombre, tú mujer...yo pensamiento y acción, tu sensibilidad y más sensibilidad" (200) ["I am a man, you are a woman...I am all thought and action, you are sensibility and more sensibility" (my translation)].

\section{Works Cited}

Ashley, Bob. The Study of Popular Fiction. Philadelphia: U of Pennsylvania P, 1989.

Bacarisse, Pamela. "Superior Men and Inferior Reality: Manuel Puig's Pubis Angelical." Bulletin of Hispanic Studies 66.4 (1989): $361-70$.

Bakhtin, Mikhail. "Discourse Typology in Prose." Readings in Russian Poetics:

Formalist and Structuralist Views. 1929. Trans. Richard Balthazar and I. R.

Titunik. Ed. Ladislav Matejka and Krystyna Pormorska. Ann Arbor:

Michigan Slavic Publications, 1978. 179-96.

Barthelme, Donald. The Dead Father. New York: Farrar, Straus \& Giroux, 1975.

- The King. New York: Harper \& Row, 1990.

_. Snow White. New York: Atheneum, 1978.

Bernal, A. Alejandro. "Super-hombre versus super-mujer: tiranía y sexo en Pubis angelical de Manuel Puig." Revista Iberoamericana 52 (1986): 99197.

Bruss, Paul. Victims. Textual Strategies in Recent American Fiction. Lewisburg, PA: Bucknell UP, 1981. 
Cheever, Leonard. "Lacan, Argentine Politics and Science Fiction in Manuel Puig's Pubis angelical." South Central Review 5 (1988): 61-74.

Couturier, Maurice, and Regis Durand. Donald Barthelme. London: Metheun, 1982.

Grimm, Jacob, and Wilhelm Grimm. The Complete Grimm's Fairy Tales. Introd. Padraic Colum. Trans. Margaret Hunt. New York: Pantheon, 1972.

Horn, Katalin. " 'The Hair Is Black as Ebony...' The Function of the Märchen in Donald Barthelme's Snow White." Orbis Litererarum 38 (1983): 271-79.

Hutcheon, Linda. A Poetics of Postmodernism. New York: Routledge, 1988.

- A Theory of Parody: The Teachings of Twentieth-Century Art Forms. New York: Metheun, 1985.

Jessen, Patricia B. "Pubis Angelical: Paradigma de la construcción social/política en la narrativa de Manuel Puig." RLA: Romance Languages Annual 1989 (1990): 481-87.

Kerr, Lucille. Reclaiming the Author: Figures and Fictions from Spanish America. Durham: Duke UP, 1992.

Lewis, Bart L. "Pubis angelical: la mujer codificada." Revista iberoamericana 49 (1983): 531-40.

Maltby, Paul. Dissident Postmodernists. Barthelme, Coover, Pynchon. Philadelphia: U of Pennsylvania P, 1991.

McCaffery, Larry, ed. Postmodern Fiction: A Bio-Bibliographical Guide. New York: Greenwood Press, 1986.

McHale, Brian. Postmodemist Fiction. New York: Methuen, 1987.

Morace, Robert A. "Donald Barthelme's Snow White: The Novel, The Critics, and The Culture." Critique: Studies in Modern Fiction 26 (1984): 1-10.

Puig, Manuel. El beso de la mujer araña. 1976. Barcelona: Seix-Barral, 1989.

-. Boquitas pintadas. Barcelona: Seix-Barral, 1972.

-. Pubis angelical. Barcelona: Seix-Barral, 1979.

—. Pubis Angelical. Trans. Elena Brunet. New York: Vintage, 1986.

Radford, Jean. The Progress of Romance. The Politics of Popular Fiction. New York: Routledge, 1986.

Sklodowska, Elzbieta. La parodia en la nueva novela hispanoamericana (19601985). Amsterdam/ Philadelphia: John Benjamins, 1991.

Solotorevsky, Myrna. "El cliché en Pubis angelical y Boquitas pintadas: Desgaste y creatividad." Hispamérica 13 (1984): 3-18.

Stott, William. "Donald Barthelme and the Death of Fiction." Prospectus. An Annual Journal of American Studies. Ed. Jack Salzman. New York: Burt Franklin \& Co., 1975.

Yúdice, George. "El beso de la mujer araña y Pubis angelical: entre el placer y el saber." Literature and Popular Culture in the Hispanic World: A Symposium. Montclair, NJ: Montclair State College, 1981. 43-57. 


\section{Journal of Popular Culture}

Alejandro Herrero-Olaizola is an Assistant Professor in the Department of Romance Languages and Literatures at the University of Michigan, Ann Arbor. $\mathrm{He}$ is the editor of Fragmented Identities: Postmodernism in Spain and Latin America, a special issue of the Journal of Interdisciplinary Literary Studies. He has also written on contemporary U.S. and Latin American fiction. 